\title{
Phenolic compounds of Bistorta alopecuroides (Turcz. ex Meissn.) Kom. (Polygonaceae) from different populations of Siberia and the Far East
}

\author{
Maria Voronkova,", and Galina Vysochina $^{1}$ \\ ${ }^{1}$ Central Siberian Botanical Garden of the Siberian Branch of the Russian Academy of Sciences, \\ 630090, Novosibirsk, Russian Federation.
}

\begin{abstract}
The article considers research of the phenolic compounds composition and content in leaves of Bistorta alopecuroides (Turcz. Ex Meissn.) Kom. from different populations using HPLC methods. It shows that $B$. alopecuroides component composition is quite variable and depends on many environmental factors, such as microclimate, altitude, technogenic pollution. Isovitixin, rutin and flavonolglycoside $\left(t_{R}=9.2 \mathrm{~min}\right.$; UV 273, $355 \mathrm{~nm}$ ) compounds are found in B. alopecuroides leaves of all studied populations. B. alopecuroides growing in high mountains and under technogenic pollution conditions have the highest content of phenolic compounds, which confirms their adaptive role in plant metabolism. The total content of phenolic compounds in leaves of $B$. alopecuroides plants reaches $20.82 \mathrm{mg} / \mathrm{g}$.
\end{abstract}

\section{Introduction}

The genus Bistorta (L.) Scop. species contain a variety of phenolic compounds anthocyanins, catechins, flavones, flavonols, phenol carboxylic acids. It is well known their anti-inflammatory, antitumoral and antibacterial properties [1]. Biological activity of B. officinalis Delarbre and B. vivipara (L.) Delarbre [2], two widely spread in Eurasia species, is being active studied. Other species of the Bistorta genus, including B. alopecuroides, have been investigated insufficiently.

Species of the Bistorta genus are high polymorphic, their morphological races are poorly isolated and have a number of transitional forms. Studying phenolic compounds is urgent to reveal important biochemical signs, to clarify the taxonomic affiliation, and to identify perspective plants for medicine use.

The article objective is to investigate the phenolic compounds composition and content in leaves of B. alopecuroides from different populations of Siberia and the Far East.

\section{Materials and Methods}

\footnotetext{
* Corresponding author: bmc_87@mail.ru
} 
The extracts of B. alopecuroides leaves of plants growing in Asian Russia were studied by HPLC. Table 1 shows sites of the samples collecting. All the plants were gathered during the flowering phase.

Table 1. B. alopecuroides samples

\begin{tabular}{|l|l|}
\hline № & \multicolumn{1}{|c|}{ Collection place } \\
\hline 1 & $\begin{array}{l}\text { The Republic of Buryatia, Tunka District, right bank of the Margasan River inflow, } \\
\text { mixed forest canopy }\end{array}$ \\
\hline 2 & $\begin{array}{l}\text { Transbaikal Region, Duldurgin District, Ara-Ilya settlement surroundings, "Alkhanai” } \\
\text { National Park cordon, Dybyksa tract }\end{array}$ \\
\hline 3 & Amur Region, Oktyabrsky District, Erkovets coal open cast, reed-grass meadow \\
\hline 4 & Amur Region, Mazanov district, Lebedikha village surroundings \\
\hline 5 & $\begin{array}{l}\text { The Republic of Buryatia, Tunka District, Nilovka settlement surroundings, Nilova } \\
\text { Pustyn' resort, the Ikhe-Ugun River bank, pine-birch-willow forest, 919 m above s.l. }\end{array}$ \\
\hline 6 & $\begin{array}{l}\text { Amur Region, Blagoveshchensk city, 11-12 km of Novo-Troitsk autoroad, dry } \\
\text { meadow }\end{array}$ \\
\hline 7 & $\begin{array}{l}\text { Amur Region, Blagoveshchensk District, 47 km of Ignatievsk autoroad, Mikhailov } \\
\text { Pillars }\end{array}$ \\
\hline 8 & $\begin{array}{l}\text { Irkutsk Region, the Zunduk River riht bank, Lake Baikal shore, paludified peddle } \\
\text { stones }\end{array}$ \\
\hline 9 & Amur Region, Blagoveshchensk city, 10-11 km of Novo-Troitsk autoroad \\
\hline 10 & $\begin{array}{l}\text { The Republic of Buryatia, Zakamensk District, Bayangola settlement surroundings, } \\
\text { the Sangina River right bank, deciduous forest (burnt), 1140 m above s.l. }\end{array}$ \\
\hline
\end{tabular}

The analysis of glycosides in water-ethanol extracts was carried out by highperformance liquid chromatography on the analytical HPLC system consisting of Agilent 1200 liquid chromatograph with a diode array detector and ChemStation, a system for collecting and processing chromatographic data. The separation was done on a Zorbax SBC18 column $4.6 \times 150 \mathrm{~mm}$ in size, with a particle diameter of $5 \mu \mathrm{m}$ using a gradient elution mode. To separate glycosides in the mobile phase, the methanol content in the aqueous solution of orthophosphoric acid $(0.1 \%)$ varied from 32 to $33 \%$ in 27 minutes; from 33 to $46 \%$ since 27 to 38 minutes; from 46 to $56 \%$ since 38 to 50 minutes. The volume of the injected sample was $5 \mu \mathrm{l}$, the eluent flow rate $-1 \mathrm{ml} / \mathrm{min}$, under column temperature $26^{\circ} \mathrm{C}$. [3]. The quantitative detection of individual compounds in eluates was carried with an external standard [4]. The content of phenolic compounds was calculated as milligram of quercetin equivalents per gram dry weight of sample $(\mathrm{mg} \mathrm{QE} / \mathrm{g})$.

\section{Results}

The analysis of the phenolic compounds composition in B. alopecuroides leaves using HPLC identify five components - vitexin (5) $\left(t_{R}=12,0\right)$, isovitexin $(6)\left(t_{R}=16,2\right)$, hyperoside (7) $\left(t_{R}=18,3\right)$, isoquercitrin $(8)\left(t_{R}=19.8\right)$, rutin $(9)\left(t_{R}=20.6\right)$. An absorption spectrum of unidentified components has two bands, one of which (II band) is in the low-wave part $(250-290 \mathrm{~nm})$, the other - in the long-wave one $(340-380 \mathrm{~nm}$ ) (band I), that is a characteristic feature of the flavonoid structure [5]. All components were attributed to phenolic compounds based on these data. Table 2 provides data on the content of individual components in leaves of $B$. alopecuroides plants. The sample number corresponds to Table

Table 2. Phenolic compounds composition and content of B. alopecuroides plant leaves 


\begin{tabular}{|c|c|c|c|c|c|c|c|c|c|c|c|}
\hline \multicolumn{2}{|c|}{ Compounds } & \multicolumn{10}{|c|}{ Sample No. } \\
\hline $\begin{array}{l}\mathrm{N} \\
\mathrm{o} .\end{array}$ & $t_{R}$ & 1 & 2 & 3 & 4 & 5 & 6 & 7 & 8 & 9 & 10 \\
\hline 1 & 7.4 & 0 & 0.34 & 0 & 0 & 0 & 0 & 0 & 0 & 0 & 0 \\
\hline 2 & 8.3 & 0 & 3.12 & 0.08 & 0.72 & 0 & 0 & 0 & 0.70 & 0 & 0 \\
\hline 3 & 9.2 & 0.19 & 0.11 & 1.83 & 1.81 & 10.46 & 6.15 & 5.63 & 5.12 & 9.37 & 4.38 \\
\hline 4 & 11.1 & 0.29 & 0 & 1.39 & 0.44 & 4.40 & 0.45 & 1.82 & 2.59 & 0 & 0.42 \\
\hline 5 & 12.0 & 0.24 & 0 & 0 & 0.47 & 0.66 & 0 & 0 & 0.09 & 0 & 0 \\
\hline 6 & 16.2 & 0.68 & 2.04 & 1.06 & 3.03 & 0.59 & 0.57 & 0.94 & 0.95 & 0.89 & 0.81 \\
\hline 7 & 18.3 & 0.67 & 0 & 1.71 & 0 & 0.63 & 0 & 1.58 & 0.60 & 1.33 & 2.23 \\
\hline 8 & 19.8 & 0.63 & 0 & 0.94 & 0 & 1.80 & 4.75 & 0.33 & 1.44 & 2.44 & 3.11 \\
\hline 9 & 20.6 & 2.56 & 1.50 & 0.76 & 0.89 & 2.28 & 1.67 & 0.92 & 0.61 & 2.82 & 1.62 \\
\hline 10 & 22.8 & 0 & 0 & 0 & 0 & 0 & 0 & 0 & 0 & 0 & 2.03 \\
\hline 11 & 24.5 & 0 & 0 & 0 & 0 & 0 & 0 & 0 & 0 & 0 & 0.20 \\
\hline 12 & 35.7 & 0 & 0.29 & 0.09 & 0 & 0 & 0.18 & 0.16 & 0 & 0.19 & 0.84 \\
\hline 13 & 40.3 & 0 & 0 & 0 & 0.09 & 0 & 0 & 0 & 0 & 0 & 0 \\
\hline 14 & 44.5 & 0 & 0.07 & 0 & 0 & 0 & 0 & 0 & 0 & 0 & 0 \\
\hline \multicolumn{2}{|c|}{$\Sigma$} & 5.26 & 7.47 & 7.86 & 7.45 & 20.82 & 13.77 & 11.38 & 12.10 & 17.04 & $\begin{array}{c}15.6 \\
4\end{array}$ \\
\hline
\end{tabular}

The relative standard deviation of repeatability in determining phenolic compounds was $0.011 ; t_{R}$ retention time, min; No. of compounds: 5 - vitexin $\left(t_{R}=12,0\right), 6$ - isovitexin $\left(t_{R}=16,2\right), 7$ - hyperoside $\left(t_{R}=18,3\right), 8$ - isoquercitrin $\left(t_{R}=19.8\right), 9$ - rutin $\left(t_{R}=20.6\right)$;

\section{Discussion}

B. alopecuroides as a typical mesophyte lives in humid, more or less solonetz meadows, swamp margins, stony slopes and pebbles, meadow steppes. It is spread mainly in Transbaikalia, except for highlands, eastward it is noted in the Amur River valley and PreKhanka lowland [6]. It was marked 14 components in total for B. alopecuroides, 5 of them - 1, 10,11, 13, 14 - were sporadic (Table 2). The maximum composition ( 9 components) was noted in sample No. 10 collected in the Republic of Buryatia at $1140 \mathrm{~m}$ above sea level, the minimum composition (6 components) - in the leaves of plants No. 6 and 9 from the Blagoveschensk District. Routine, isovitoxin and unidentified component No. $3\left(t_{R}=\right.$ $9.2 \mathrm{~min}$; UV spectrum - 273,355 nm) were found in all studied samples; hyperoside, isoquercitrine, astragaline and unidentified compound No. $4\left(t_{R}=11,1\right)$ were frequently occurring compounds as well. The phenolic components composition in leaves of B. alopecuroides from different populations is quite variable, which may be due to both environmental factors (soil composition, microclimate, altitude, technogenic pollution), and to a possible hybridization of this species with the widespread in Eurasia B. officinalis Delarbre. This hypothesis on the hybridization of $B$. alopecuroides and B. officinalis Delarbre, and the origin of the species B. elliptica (Willd. Ex Spreng.) Kom as a result of such hybridization belonged to N. N. Tsvelev [6]. In general, the Bistorta genus species are characterized with a great polymosphism, they are often represented by numerous weakly differentiated races [7]. M.G. Popov [8] noted that B. alopecuroides in a typical form occurs only in "Proper Dauria: for example, Nerchinsk Plant and along the River Argun". Phenolic compounds are involved in many important processes of plant metabolism, and morphological variability is closely related to changes in chemical composition.

Variability was marked for the quantitative content of phenolic compounds as well. The smallest content of phenolic compounds $(5.26 \mathrm{mg}$ QE/g) was fixed in plant leaves collected in the Republic of Buryatia (No. 1) growing under the mixed forest canopy, the greatest one (20.8 mg QE/g) in plants from Tunka District in Buryatia (No. 5), which grew at $919 \mathrm{~m}$ 
above sea level. Plants gathered at $1140 \mathrm{~m}$ above sea level (No. 10) have a high content (15.64 mg QE/g) as well. Samples growing in Blagoveshchensk city surroundings (No. 6, 9) collected near the road contain up to $13.87-17.04 \mathrm{mg}$ QE/g of phenolic compounds with the lowest composition of 6 components that is confirmed by numerous references on the enhanced synthesis of phenolic compounds, including flavonoids, under effect of various stresses. The flavonoid accumulation by plants is a mechanism to protect their photosynthetic apparatus from extensive oxidation under the influence of higher insolation or man-made contamination $[9,10]$. In the remaining samples the phenolic compounds content in leaves was about $7.5 \mathrm{mg} \mathrm{QE} / \mathrm{g}$.

In conclusion, the composition and content of phenolic components of B. alopecuroides from different populations of Siberia and the Far East is quite variable and depends on environmental factors, such as soil composition, microclimate, altitude, technogenic pollution. Three components were identified, which were found in B. alopecuroides plant leaves of all studied populations: isovitixine, rutin and unidentified component No. $3\left(t_{R}=\right.$ $9.2 \mathrm{~min}$; UV spectrum $273,355 \mathrm{~nm}$ ). B. alopecuroides plants growing in highlands and under conditions of technogenic pollution have the highest content of phenolic compounds that confirms the adaptive role of phenolic compounds in plant metabolism.

\section{References}

1. M. Adiba, I. H. M. Tabarak, Glob J. Res Med Plants Indigenous Med 2, 669-674 (2013)

2. M. S. Voronkova, G. I.Vysochina, Chem. Sustainable Development 22, 209-215 (2014).

3. E. P. Khramova, E. K. Komarevtseva, Vegetative Resources 44, 96-102 (2008) In Russ.

4. T. A. Van Beek, J. Chromatography A 967, 21-35 (2002)

5. E. P. Khramova, Chem. Vegetative Raw Materials 1, 185-193 (2014.) In Russ.

6. N. N. Tsvelyov. Vascular plants of the Soviet Far East (4, Nauka, Leningrad, 1989) In Russ.

7. V. V. Petrovsky, Arctic flora of the USSR 5 (Nauka, Moscow, 1966.) In Russ.

8. M. G. Popov, Flora of Middle Siberia 2 (Nauka, Moscow, Leningrad, 1959) In Russ.

9. E. Grotewold, The science of flavonoids (Springer, New York, 2006)

10. M. S. Voronkova, G. I.Vysochina, Contemp. Probl. Ecology 6, 565-574 (2013) 